\title{
Corrosion Behaviour of Ti-6Al-4V Alloy with Nitride Coatings in Simulated Body Fluids at $36^{\circ} \mathrm{C}$ and $40^{\circ} \mathrm{C}$
}

\author{
I. M. Pohrelyuk, O. V. Tkachuk, and R. V. Proskurnyak \\ Karpenko Physico-Mechanical Institute, National Academy of Sciences of Ukraine, 5 Naukova Street, Lviv 79060, Ukraine \\ Correspondence should be addressed to I. M. Pohrelyuk; pohreliuk@mail.ru
}

Received 31 October 2012; Accepted 2 December 2012

Academic Editors: G. Bereket, C.-H. Hsu, and R. Wang

Copyright (C) 2013 I. M. Pohrelyuk et al. This is an open access article distributed under the Creative Commons Attribution License, which permits unrestricted use, distribution, and reproduction in any medium, provided the original work is properly cited.

Nitride coatings were formed on Ti-6Al-4V alloy by thermodiffusion treatment. The corrosion-electrochemical behaviour of Ti$6 \mathrm{Al}-4 \mathrm{~V}$ alloy with nitride coatings I and II was investigated in physiological solutions $(0.9 \% \mathrm{NaCl}$ and Tyrode's) at temperatures of $36^{\circ} \mathrm{C}$ and $40^{\circ} \mathrm{C}$. It is determined that nitride coating I provides Ti-6Al-4V alloy the higher corrosion resistance in Tyrode's solution at both temperatures of solution while nitride coating II in isotonic $0.9 \% \mathrm{NaCl}$.

\section{Introduction}

Titanium and its alloys are widely used in dentistry and orthopedics [1-4]. They provide high biomechanical properties and chemical stability in biological systems than other materials such as stainless steel and cobalt-chromium alloys. Ti$6 \mathrm{Al}-4 \mathrm{~V}$ alloy has better physical and mechanical properties than titanium, but has a low corrosion resistance $[2,5,6]$.

Surface treatment is widely used to enhance abrasion, corrosion resistance, and surface hardness [2, 3, 7, 8]. Nitriding is often used to harden the titanium alloy surface [3, 911]. Good biocompatibility of titanium nitride is shown in the blood and bone tissue [11]. In addition, the titanium nitride is characterized by good mechanical, tribological, and anticorrosion properties. That is why the titanium nitride is the most suitable to protect the surface of medical implants.

One of the main criteria to use material as implant is its corrosion resistance in physiological solution that simulates the environment of the human body [12]. In particular, isotonic $0.9 \% \mathrm{NaCl}$ solution simulates blood plasma and Tyrode's solution biological tissue.

The temperature increase is a protective reaction to the penetration of infection or inflammation. When the physiological solution temperature changes, the transition from normal to inflammatory state of the human body can occur.
Purpose is to examine the corrosion-electrochemical behaviour of Ti-6Al-4V alloy with nitride coatings in physiological solutions at $36^{\circ} \mathrm{C}$ and $40^{\circ} \mathrm{C}$.

\section{Experimental}

Samples of $(\alpha+\beta)$ Ti-6Al-4V alloy (wt\%: C-0.1; H-0.015; N0.04; O-0.15; Fe-0.25; Al-6.0; V-4.0; Ti-bal.) with dimensions $10 \times 15 \times 1 \mathrm{~mm}$ were investigated. Before chemical-thermal treatment, the samples were polished by diamond paste to a surface roughness of $R_{a}=0.4 \mu \mathrm{m}$. Then, they were washed in alcohol and dried.

Thermodiffusion saturation by nitrogen was carried out at $T=850^{\circ} \mathrm{C}$ for $\tau=12 \mathrm{~h}$. The samples were heated to the nitriding temperature in a vacuum of $10^{-3} \mathrm{~Pa}$. Heating rate was $0.040^{\circ} \mathrm{C} / \mathrm{s}$. After the isothermal exposure, the samples were cooled in nitrogen with the furnace at an average cooling rate of $0.028^{\circ} \mathrm{C} / \mathrm{s}$. After cooling to $500^{\circ} \mathrm{C}$, the system was vacuumized. Nitride coatings I and II on Ti-6Al-4V alloy were formed at two different nitrogen partial pressures: (I) $p_{N_{2}}=1 \mathrm{~Pa}$, gas flow rate $I=7 \times 10^{-3} \mathrm{~Pa} / \mathrm{s}$ (dynamic conditions) and (II) $p_{N_{2}}=10^{5} \mathrm{~Pa}$ (static conditions).

Nitrogen gas of the technical purity was used. It contained oxygen not more than 0.4 vol\% and water vapour up to $0.07 \mathrm{~g} / \mathrm{m}^{3}$. The oxygen and moisture in the nitrogen 
atmosphere were removed by filtering the gas through a silica gel filter and heating the titanium chips at $50^{\circ} \mathrm{C}$ above the nitriding temperature.

The content of each nitride in nitride zone depends on the nitrogen partial pressure during nitriding [13]. It was formed two types of nitride coating: I and II (Figure 1), by changing the gas dynamic conditions in the reaction chamber. These coatings are different because of their ratio values of nitride layer components: nitrides $\delta$-TiN and $\varepsilon-\mathrm{Ti}_{2} \mathrm{~N}$. Coating I is characterized by thin nitride film which contains $\varepsilon-\mathrm{Ti}_{2} \mathrm{~N}$ mainly and coating II by thick nitride film which contains $\delta$ TiN mainly. Nitride zone is delimited from a matrix alloy by diffusion layer $\operatorname{Ti}(\mathrm{N})$. The characteristic surface topography is formed in coating II through the formation and growth of $\delta$-TiN layer. It worsens the quality of nitrided surface.

Phase composition of the surface layers after nitriding was determined by $\mathrm{X}$-ray phase analysis $\left(\mathrm{CuK}_{\alpha}\right.$ radiation). The tube focusing system was made using Bragg-Brentano method. Voltage on the anode of X-ray tube was of $40 \mathrm{kV}$ and current density was of $30 \mathrm{~mA}$. The scan step was $0.02^{\circ}$ and rate was $10^{\circ} / \mathrm{min}$. The diffraction patterns were refined using Sietronix and Powder Cell 2.4 programs, by means of which one conducted Fourier analysis of diffractograms and determined the places of diffraction maximums of reflection identified from data of card index of JCPDS-ASTM phases.

Surface microstructure of the surface layers was carried out by scanning electron microscope EVO-40XVP.

Chemical composition of the surface layers was determined by energy dispersive X-ray spectrometer INCA ENERGY 350 and X-ray fluorescence spectrometer EXPERT 02L.

The profilograms of samples surface were received after nitriding. Quantitative characteristics of the surface microgeometry (height parameters of $R_{a}, R_{z}$, and $R_{\max }$ and footpace parameters of $S$, and $S_{m}$ ) were determined by special programs.

The electrochemical tests of Ti-6Al-4V alloy with nitride coatings were carried out in isotonic $0.9 \% \mathrm{NaCl}$ solution and Tyrode's solution (g/L: NaCl-8.00; $\mathrm{CaCl}_{2}-0.20$; KCl-0.20; $\left.\mathrm{NaHCO}_{3}-0.10 ; \mathrm{MgCl}_{2}-6 \mathrm{H}_{2} \mathrm{O}-0.10 ; \mathrm{NaH}_{2} \mathrm{PO}_{4}-0.10\right)$ using IPC-pro potentiostat. Experiments were performed at solution temperatures of $36^{\circ} \mathrm{C}$ and $40^{\circ} \mathrm{C}$. By changing the temperature of the solution, we simulated the transition from normal to inflammatory state of the human body. Three-electrode glass cell with a platinum counter electrode and a saturated $\mathrm{Ag} / \mathrm{AgCl}$ reference electrode was used. Surface of the working electrode of Ti-6Al-4V alloy was coated with epoxy resin, leaving area for exposure to the electrolyte of $1 \mathrm{~cm}^{2}$. The polarization curves for Ti-6Al-4V alloy with nitride coatings were recorded in the potential range $-1.0-2.5 \mathrm{~V}$ versus $\mathrm{Ag} / \mathrm{AgCl}$ at a scan rate of $2 \mathrm{mV} / \mathrm{s}$.

\section{Results and Discussion}

Nitride zone is formed during nitriding of Ti-6Al-4V alloy. According to the results of $\mathrm{X}$-ray phase analysis, it contains titanium nitrides TiN and $\mathrm{Ti}_{2} \mathrm{~N}$ (Figure 2). Nitride coating I formed during nitriding at $p_{N_{2}}=1 \mathrm{~Pa}$ has $4 \%$ of TiN.
However, nitride coating II formed during nitriding at $p_{\mathrm{N}_{2}}=$ $10^{5} \mathrm{~Pa}$ has $67 \%$ of TiN. So, nitride coating I mainly contains $\mathcal{E}$ $\mathrm{Ti}_{2} \mathrm{~N}$ and nitride coating II $\delta$-TiN. Nitride zone of the coating II is twice thicker than coating I ( 7 and $3 \mu \mathrm{m}$, resp.).

The quality of nitrided surface depends on the formed coating. Quantitative characteristics of the surface microgeometry indicate that the surface quality of coating II is worse than coating I (Figure 3).

We will consider the corrosion-electrochemical behaviour of Ti-6Al-4V alloy with nitride coatings I and II in physiological solutions.

\subsection{Nitride Coating I}

At $36^{\circ} \mathrm{C}$. Two peaks of increase of anode current density at 0.07 and $0.3 \mathrm{~V}$ are observed on the anodic branch of the polarization curve of nitride coating I in $0.9 \% \mathrm{NaCl}$ after the region of active dissolution (Figure 4(a), curve 1). The reason for this behaviour is the dissolution of nitride film with formation titanium oxynitride and titanium oxide of nonstoichiometric composition on the alloy surface [14-16] as follows:

$$
\begin{gathered}
2 \mathrm{TiN}+2 y \mathrm{H}_{2} \mathrm{O} \longrightarrow 2 \mathrm{TiN}_{x} \mathrm{O}_{y}+(1-x) \mathrm{N}_{2}+4 y \mathrm{H}^{+}+4 y \mathrm{e}^{-} \\
2 \mathrm{TiN}_{x} \mathrm{O}_{y}+2 \mathrm{H}_{2} \mathrm{O} \longrightarrow \\
+2 \mathrm{Ti}^{3+}+(y+1) \mathrm{O}_{2}+x \mathrm{~N}_{2} \\
+4 \mathrm{H}^{+}+10 \mathrm{e}^{-} \\
\mathrm{Ti}^{3+}+x \mathrm{H}_{2} \mathrm{O} \longrightarrow \mathrm{TiO}_{x}+2 x \mathrm{H}^{+}+(2 x-3) \mathrm{e}^{-}
\end{gathered}
$$

They slow the dissolution.

At the same time, the electrochemical behaviour of the nitride coating in Tyrode's solution differs. The passive region is observed in the range of potentials $-0.25-0.30 \mathrm{~V}$ (Figure 4(a), curve 2). Perhaps ions of calcium, magnesium, and phosphorus take part in the formation of a surface film. The film inhibits the dissolution of nitride coating $[17,18]$. It confirms by the results of X-ray fluorescence analysis. They fix a small mass share of these elements on the nitrided samples surface after polarization in this physiological solution (wt\%: $\mathrm{K}-0.12$, Ca-0.10). Passive current density is $0.045 \mathrm{~A} / \mathrm{m}^{2}$. Despite the fact that the corrosion potential shifts to negative potential range, corrosion current density of nitride coating I decreases in Tyrode's solution (see Table 1). Moreover, the current density of anodic dissolution decreases too.

These results indicate higher corrosion resistance of nitride coating I in a solution that simulates biological tissue (Tyrode's), compared with a solution that simulates blood plasma $(0.9 \% \mathrm{NaCl})$.

At $40^{\circ} \mathrm{C}$. Processes on the anodic branch of the polarization curve of the nitride coating I in $0.9 \% \mathrm{NaCl}$ are similar at lower temperature (Figure 4(b), curve 1). However, this coating provides higher corrosion resistance for Ti-6Al-4V alloy. It confirms by lower corrosion current density (see Table 1). It is caused by the formation of titanium oxide films. They slow the anodic dissolution $[19,20]$. 

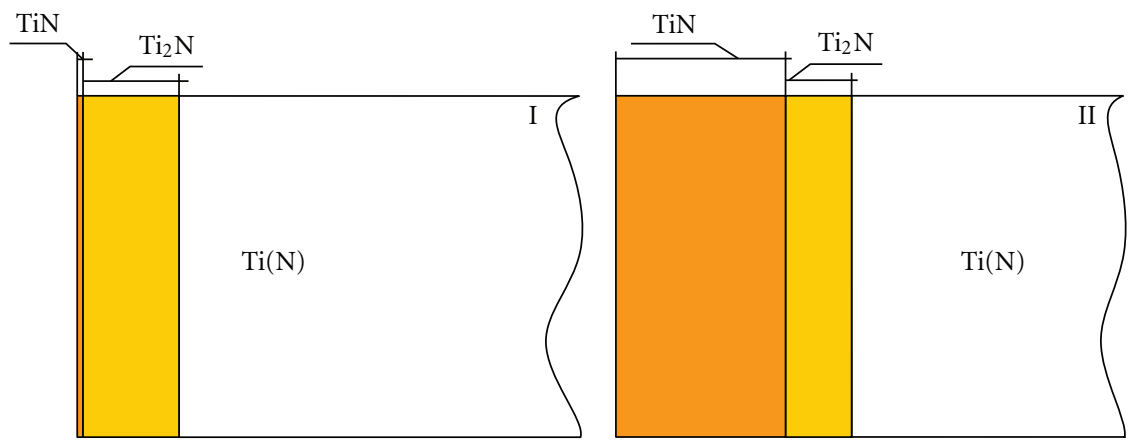

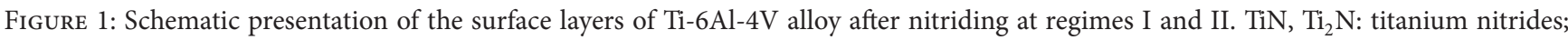
$\operatorname{Ti}(\mathrm{N})$ : solid solution of nitrogen in $\alpha$-titanium.

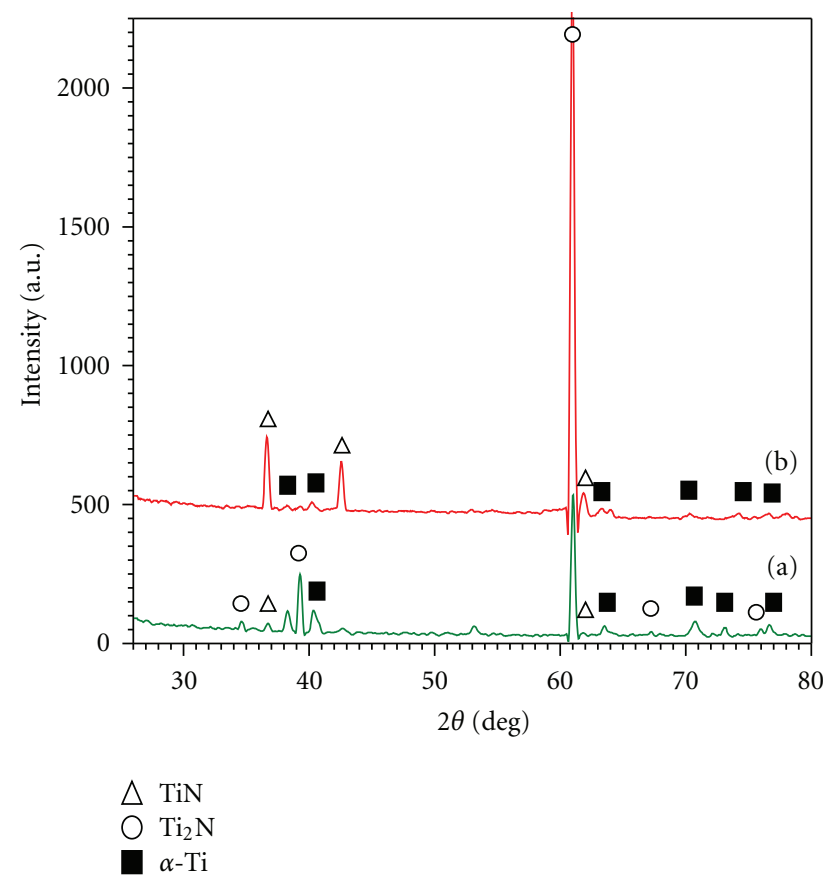

Figure 2: X-ray diffraction patterns of Ti-6Al-4V alloy after different regimes of nitriding. a: I; b: II.

TABLE 1: Corrosion parameters of Ti-6Al-4V alloy with nitride coatings I and II in physiological solutions.

\begin{tabular}{llcccc}
\hline \multirow{2}{*}{$T,{ }^{\circ} \mathrm{C}$} & Corrosion & \multicolumn{2}{c}{$0.9 \% \mathrm{NaCl}$} & \multicolumn{2}{c}{ Tyrode's solution } \\
& parameters & I & II & I & II \\
\hline \multirow{2}{*}{36} & $E_{\kappa}, \mathrm{V}$ & -0.200 & -0.285 & -0.450 & -0.600 \\
& $i_{\kappa}, \mathrm{A} / \mathrm{m}^{2}$ & 0.0060 & 0.0015 & 0.0040 & 0.0035 \\
\multirow{2}{*}{40} & $E_{\kappa}, \mathrm{V}$ & -0.300 & -0.170 & -0.400 & -0.300 \\
& $i_{\kappa}, \mathrm{A} / \mathrm{m}^{2}$ & 0.0037 & 0.0014 & 0.0030 & 0.0015 \\
\hline
\end{tabular}

The passive region is observed in the potential range of $-0.25-0.25 \mathrm{~V}$ in Tyrode's solution (Figure 4(b), curve 2 ). The passive current density is $0.02 \mathrm{~A} / \mathrm{m}^{2}$. It should be noted that the mechanism of the passing of anodic processes is similar to those observed for $36^{\circ} \mathrm{C}$. Microanalysis does not fix chlorine on the surface but only traces of calcium, magnesium, and phosphorus.

Corrosion current density in Tyrode's solution compared with $0.9 \% \mathrm{NaCl}$ solution at $40^{\circ} \mathrm{C}$ shows higher corrosion resistance of nitride coating I in these conditions (see Table 1).

Thus, better corrosion resistance of nitride coating $I$ is fixed in the solution that simulates the biological tissue (Tyrode's) during simulating the temperature variation from normal to inflammatory processes in the body.

\subsection{Nitride Coating II}

At $36^{\circ} \mathrm{C}$. Two peaks of the current density increase are observed on the anodic branch of the polarization curve of nitride coating II in $0.9 \% \mathrm{NaCl}$ at potentials $0.1-0.4 \mathrm{~V}$. It occurred due to dissolution of nitride film with formation of nonstoichiometric composition of reaction (3) on the titanium oxide surface. Its further dissolution at potentials 0.5-2.1 V (Figure 5(a), curve 1) occurs with the formation of oxychloride on the titanium surface as follows:

$$
\mathrm{TiO}_{x}+2 \mathrm{Cl}^{-} \longrightarrow \mathrm{TiO}_{x} \mathrm{Cl}_{2}+2 \mathrm{e}^{-}
$$

It is confirmed by the presence of oxygen and chlorine in the surface spectra of X-ray fluorescence analysis (6.59/8.74 and 4.19/2.51 wt/at\%, resp.).

It was observed the passive region (passive current density is $0.003 \mathrm{~A} / \mathrm{m}^{2}$ ) in Tyrode's solution, unlike $0.9 \% \mathrm{NaCl}$, in the range of potentials $-0.33-0.35 \mathrm{~V}$ (Figure $5(\mathrm{a})$, curve 2). The existence of the passive region, as in coating I, is caused by the influence of physiological solution. Chlorine ions affect the increase of the current density. They cause the formation of oxychloride by reaction (4) on the titanium surface. Oxygen and chlorine are present in the surface spectra of X-ray fluorescence analysis. From the results of the analysis (Figure 6 , Table 2), the intensification of interaction of chlorine ions with the surface should be associated with the roughness increase, especially height parameters of microrelief.

It should be noted that the current density of the anodic dissolution of coating II is lower but corrosion current density is higher than $0.9 \% \mathrm{NaCl}$. 


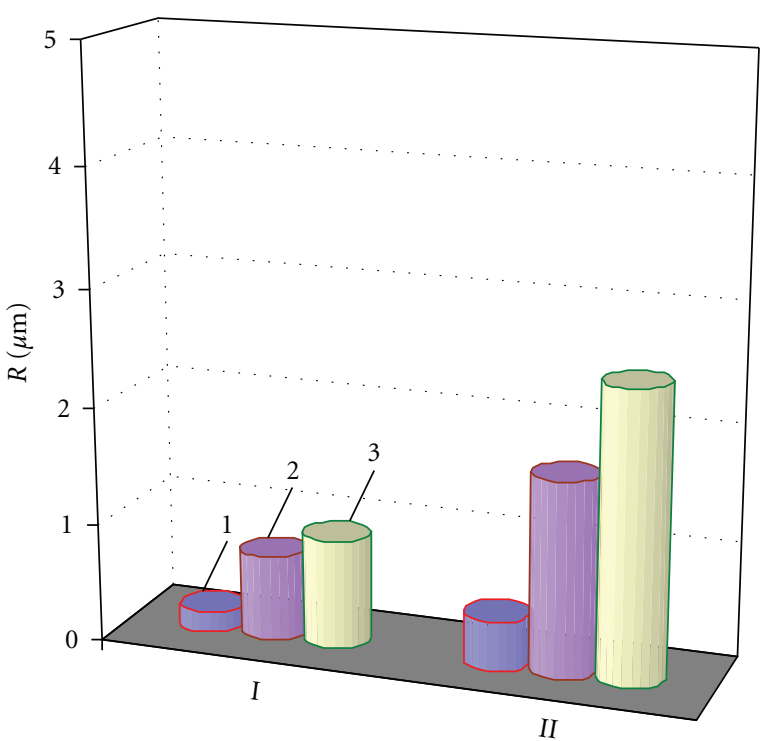

(a)

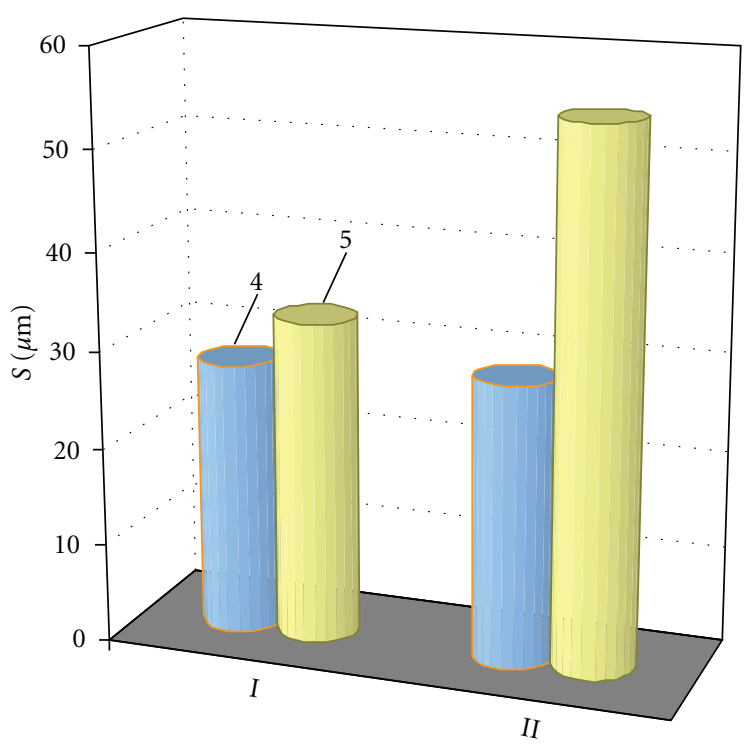

(b)

FIGURE 3: Quantitative characteristics of the surface microgeometry of Ti-6Al-4V alloy with nitride coatings I and II. (a) $1-R_{a}$; $2-R_{z}$, $3-R_{\max } ;$ (b) $4-S, 5-S_{m}$.

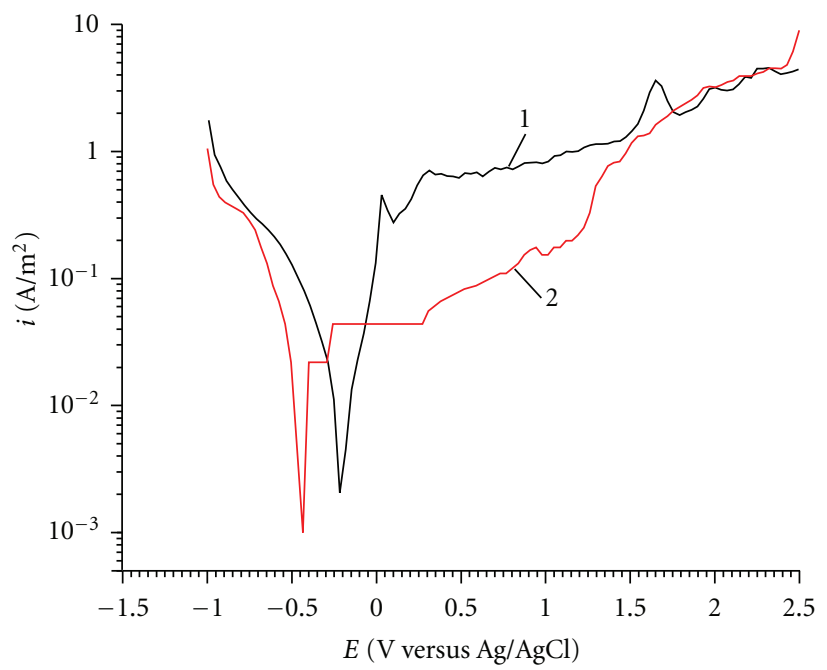

(a)

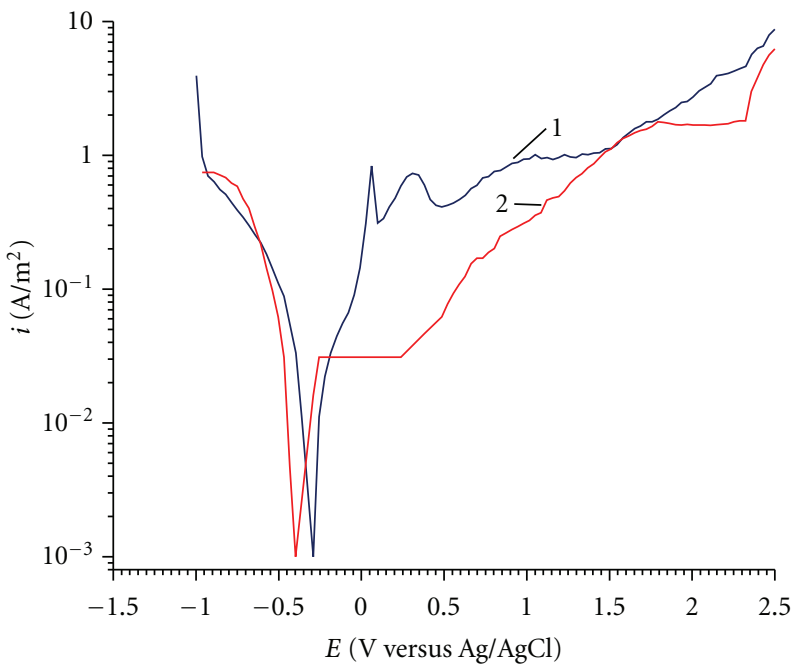

(b)

FIgURE 4: Potentiodynamic polarization curves of Ti- $6 \mathrm{Al}-4 \mathrm{~V}$ alloy with nitride coating I in $0.9 \% \mathrm{NaCl}(1)$ and Tyrode's solution (2) at $36^{\circ} \mathrm{C}$ (a) and $40^{\circ} \mathrm{C}$ (b).

Corrosion-electrochemical behaviour of nitride coatings I and II is similar, although the protective effect of coating II is higher; corrosion current density and current density of anodic dissolution are lower in $0.9 \% \mathrm{NaCl}$ and Tyrode's solution.

At $40^{\circ} \mathrm{C}$. Processes which occur in the anode region of potentials for nitride coating II in both physiological solutions are similar. Thus, the peaks at 0.05 and $0.25 \mathrm{~V}$ (Figure 5(b), curves 1 and 2) are observed on the anodic branch of the polarization curve of the coating II in $0.9 \% \mathrm{NaCl}$ and Tyrode's solution. It is caused by the formation of titanium oxynitride, oxide, and oxychloride of nonstoichiometric composition [14-16].

Although the processes for coating II in $0.9 \% \mathrm{NaCl}$ at $40^{\circ} \mathrm{C}$ in the anode region are similar as processes that are observed at $36^{\circ} \mathrm{C}$, processes of dissolution become slow because of the protective film formation with the solution temperature increase. It is confirmed by the deceleration of increase of current density at increase of potential.

Polarization curve of Ti-6Al-4V alloy with nitride coating II in Tyrode's solution at the temperature $40^{\circ} \mathrm{C}$ shows the lack of passive area. Its formation was associated with the 


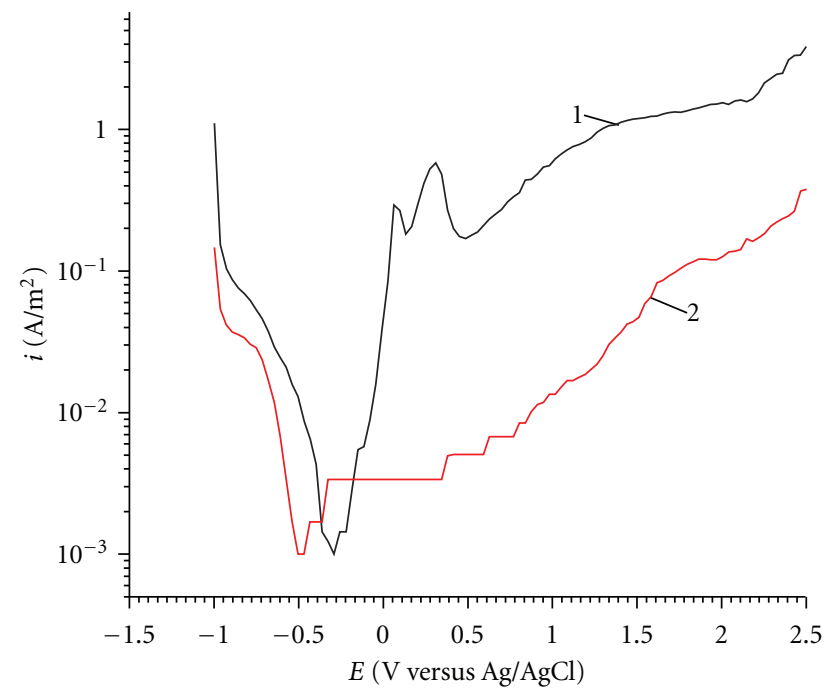

(a)

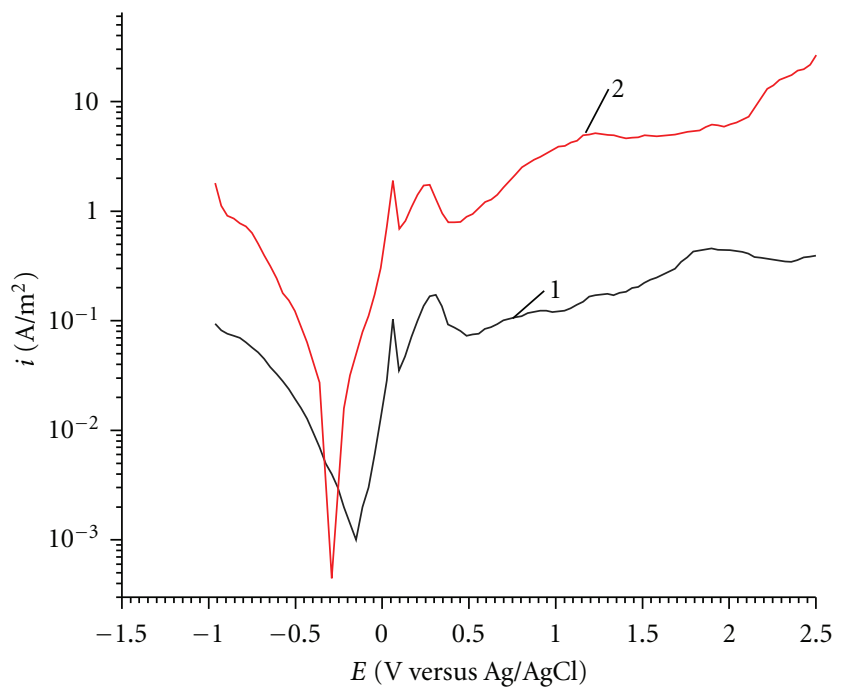

(b)

Figure 5: Potentiodynamic polarization curves of Ti-6Al-4V alloy with nitride coating II in $0.9 \% \mathrm{NaCl}(1)$ and Tyrode's solution (2) at $36^{\circ} \mathrm{C}$ (a) and $40^{\circ} \mathrm{C}(\mathrm{b})$.

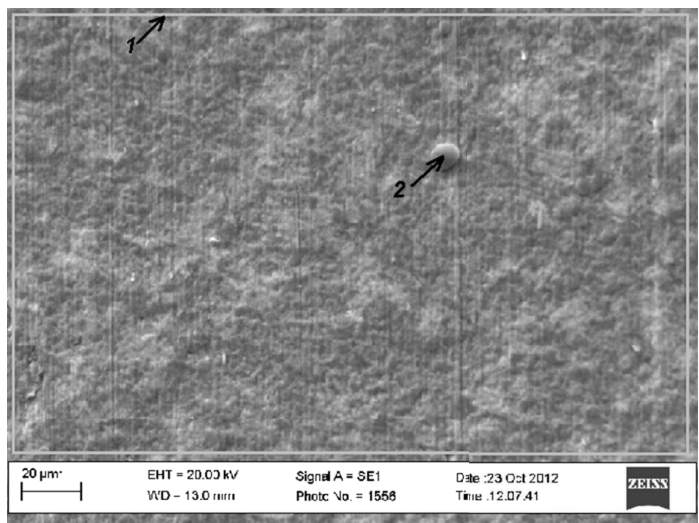

(a)

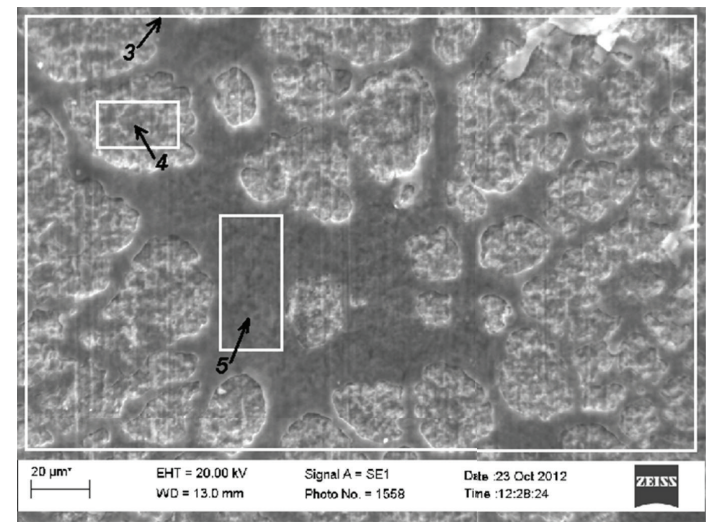

(b)

Figure 6: The surface of Ti-6Al-4V alloy with nitride coating II after polarization in Tyrode's solution at $36^{\circ} \mathrm{C}$ (a) and $40^{\circ} \mathrm{C}$ (b).

TABLE 2: Energy dispersive X-ray analysis from surface of Ti-6Al-4V alloy with nitride coating II after polarization in Tyrode’s solution.

\begin{tabular}{|c|c|c|c|c|c|}
\hline \multirow{2}{*}{ Element } & \multicolumn{5}{|c|}{ Areas of energy dispersive X-ray analysis (see Figure 6) } \\
\hline & No. 1 & No. 2 & No. 3 & No. 4 & No. 5 \\
\hline C K & - & $40.77 / 69.59$ & $10.59 / 26.89$ & - & $23.04 / 48.47$ \\
\hline N K & $13.93 / 35.49$ & - & - & $9.16 / 25.54$ & - \\
\hline $\mathrm{OK}$ & - & $5.06 / 6.48$ & $11.83 / 22.56$ & - & $9.88 / 15.61$ \\
\hline $\mathrm{Al} \mathrm{K}$ & $0.30 / 0.40$ & $0.13 / 0.10$ & $0.30 / 0.34$ & $0.34 / 0.49$ & $0.26 / 0.24$ \\
\hline $\mathrm{Cl} \mathrm{K}$ & $0.72 / 0.72$ & $4.65 / 2.69$ & $4.44 / 3.82$ & $0.61 / 0.68$ & $2.43 / 1.73$ \\
\hline P K & $0.05 / 0.06$ & - & - & - & - \\
\hline $\mathrm{Ca} \mathrm{K}$ & $0.03 / 0.03$ & - & - & - & - \\
\hline Ti K & $84.98 / 63.31$ & $49.40 / 21.14$ & $72.84 / 46.39$ & $89.89 / 73.9$ & $64.38 / 33.95$ \\
\hline
\end{tabular}

Numerator: wt\%; denominator: at\%. 
composition of physiological solution (Figure 5(b), curve 2). Perhaps the corrosion-electrochemical behaviour of the coating II in these conditions is associated with a change of the dominant processes of oxidation-reduction reaction by increasing the surface roughness. This assumption is confirmed by the results of energy dispersive X-ray and Xray fluorescence analyses. They demonstrate the high content of chlorine on the surface of the samples after anodic polarization, and its concentration increases at high-altitude maximums of surface microrelief (Figure 6, Table 2).

Stable electrochemical properties of the nitride coating II in $0.9 \% \mathrm{NaCl}$ confirmed the higher functionality (corrosion protection) in this solution compared with Tyrode's solution.

In general, the nitride coating II formed during nitriding at $p_{\mathrm{N}_{2}}=10^{5} \mathrm{~Pa}$ provides Ti-6Al-4V alloy the higher corrosion resistance in physiological solutions. It occurs by means of stronger shielding effect (thickness of nitride layer), the higher strength of chemical bonds in TiN phase, and more of its content in the nitride coating.

\section{Conclusions}

Nitride coating formed on Ti-6Al-4V alloy during nitriding at $p_{N_{2}}=1$ Pa regardless of temperature of physiological solution shows higher corrosion resistance in Tyrode's solution, simulating biological tissue, while nitride coating formed during nitriding at $p_{\mathrm{N}_{2}}=10^{5} \mathrm{~Pa}$ in isotonic $0.9 \% \mathrm{NaCl}$, simulating blood plasma.

Increased activity of chlorine ions of physiological solution is associated with microrelief of nitride coating.

Raising the temperature of physiological solution from $36^{\circ} \mathrm{C}$ to $40^{\circ} \mathrm{C}$, simulating the transition from normal to inflammatory state of the human body affects the electrochemical behaviour of nitride coating and, especially in solution, simulates biological tissue (Tyrode's).

\section{Acknowledgments}

This work is supported by the State Fund for Fundamental Researchers and the State Agency on Science, Innovations and Informatization of Ukraine (Project no. F41.2/011).

\section{References}

[1] S. Krischok, C. Blank, M. Engel et al., "Influence of ion implantation on titanium surfaces for medical applications," Surface Science, vol. 601, no. 18, pp. 3856-3860, 2007.

[2] F. Variola, J. H. Yi, L. Richert, J. D. Wuest, F. Rosei, and A. Nanci, "Tailoring the surface properties of Ti6Al4V by controlled chemical oxidation," Biomaterials, vol. 29, no. 10, pp. 1285-1298, 2008.

[3] F. Yildiz, A. F. Yetim, A. Alsaran, and I. Efeoglu, "Wear and corrosion behaviour of various surface treated medical grade titanium alloy in bio-simulated environment," Wear, vol. 267, no. 5-8, pp. 695-701, 2009.

[4] T. Chang-Bin, L. Dao-Xin, W. Zhan, and G. Yang, "Electrospark alloying using graphite electrode on titanium alloy surface for biomedical applications," Applied Surface Science, vol. 257, no. 15 , pp. 6364-6371, 2011.

[5] M. Metikos-Hukovic, A. Kwokal, and J. Piljac, "The influence of niobium and vanadium on passivityof titanium-based implants in physiological solution," Biomaterials, vol. 24, pp. 3765-3775, 2003.

[6] I. Cvijovic-Alagic, Z. Cvijovic, S. Mitrovic, V. Panic, and M. Rakin, "Wear and corrosion behaviour of Ti-13Nb-13Zr and Ti-6Al-4V alloys in simulated physiological solution," Corrosion Science, vol. 53, pp. 796-808, 2011.

[7] D. V. Shtansky, N. A. Gloushankova, A. N. Sheveiko et al., "Design, characterization and testing of Ti-based multicomponent coatings for load-bearing medical applications," Biomaterials, vol. 26, no. 16, pp. 2909-2924, 2005.

[8] L. Wang, J. F. Su, and X. Nie, "Corrosion and tribological properties and impact fatigue behaviors of TiN- and DLCcoated stainless steels in a simulated body fluid environment," Surface and Coatings Technology, vol. 205, no. 5, pp. 1599-1605, 2010.

[9] P. Budzynski, A. A. Youssef, and J. Sielanko, "Surface modification of Ti-6Al-4V alloy by nitrogen ion implantation," Wear, vol. 261, pp. 1271-1276, 2006.

[10] T. M. Manhabosco, S. M. Tamborim, C. B. dos Santos, and I. L. Müller, "Tribological, electrochemical and triboelectrochemical characterization of bare and nitrided Ti6Al4V in simulated body fluid solution," Corrosion Science, vol. 53, no. 5, pp. 1786-1793, 2011.

[11] B. Subramanian, C. V. Muraleedharan, R. Ananthakumar, and M. Jayachandran, "A comparative study of titanium nitride (TiN), titanium oxy nitride (TiON) and titanium aluminum nitride (TiAlN), as surface coatings for bio implants," Surface and Coatings Technology, vol. 205, no. 21-22, pp. 5014-5020, 2011.

[12] S. Barril, S. Mischler, and D. Landolt, "Electrochemical effects on the fretting corrosion behaviour of Ti6Al4V in $0.9 \%$ sodium chloride solution," Wear, vol. 259, no. 1-6, pp. 282-291, 2005.

[13] I. M. Pohrelyuk, O. V. Tkachuk, and R. V. Proskurnyak, "Corrosion resistance of the Ti-6Al-4V titanium alloy with nitride coatings in $0.9 \% \mathrm{NaCl}$," Journal of the Minerals, Metals and Materials Society, vol. 63, no. 6, pp. 35-40, 2011.

[14] V. A. Lavrenko, V. A. Shvets, N. V. Boshitskaya, and G. N. Makarenko, "Comparative study of the chemical resistance of titanium nitride and stainless steel in media of the oral cavity," Powder Metallurgy and Metal Ceramics, vol. 40, no. 11-12, pp. 630-636, 2001.

[15] T. H. Fang and K. T. Wu, "Local oxidation characteristics on titanium nitride film by electrochemical nanolithography with carbon nanotube tip," Electrochemistry Communications, vol. 8, no. 1, pp. 173-178, 2006.

[16] R. S. Razavi, M. Salehi, M. Ramazani, and H. C. Man, "Corrosion behaviour of laser gas nitrided Ti-6Al-4V in $\mathrm{HCl}$ solution," Corrosion Science, vol. 51, no. 10, pp. 2324-2329, 2009.

[17] H. Takadama, H. M. Kim, T. Kokubo, and T. Nakamura, "XPS study of the process of apatite formation on bioactive Ti-6Al$4 \mathrm{~V}$ alloy in simulated body fluid," Science and Technology of Advanced Materials, vol. 2, no. 2, pp. 389-396, 2001.

[18] C. Vasilescu, S. I. Drob, E. I. Neacsu, and J. C. M. Rosca, "Surface analysis and corrosion resistance of a new titanium base alloy in simulated body fluids," Corrosion Science, vol. 65, pp. 431-440, 2012. 
[19] J. Zhang, L. Duan, D. Jiang, Q. Lin, and M. Iwasa, "Dispersion of TiN in aqueous media," Journal of Colloid and Interface Science, vol. 286, no. 1, pp. 209-215, 2005.

[20] V. A. Lavrenko, A. D. Panasyuk, M. Desmaison-Brut, V. A. Shvets, and J. Desmaison, "Kinetics and mechanism of electrolytic corrosion of titanium-based ceramics in $3 \% \mathrm{NaCl}$ solution," Journal of the European Ceramic Society, vol. 25, no. 10, pp. 1813-1818, 2005. 

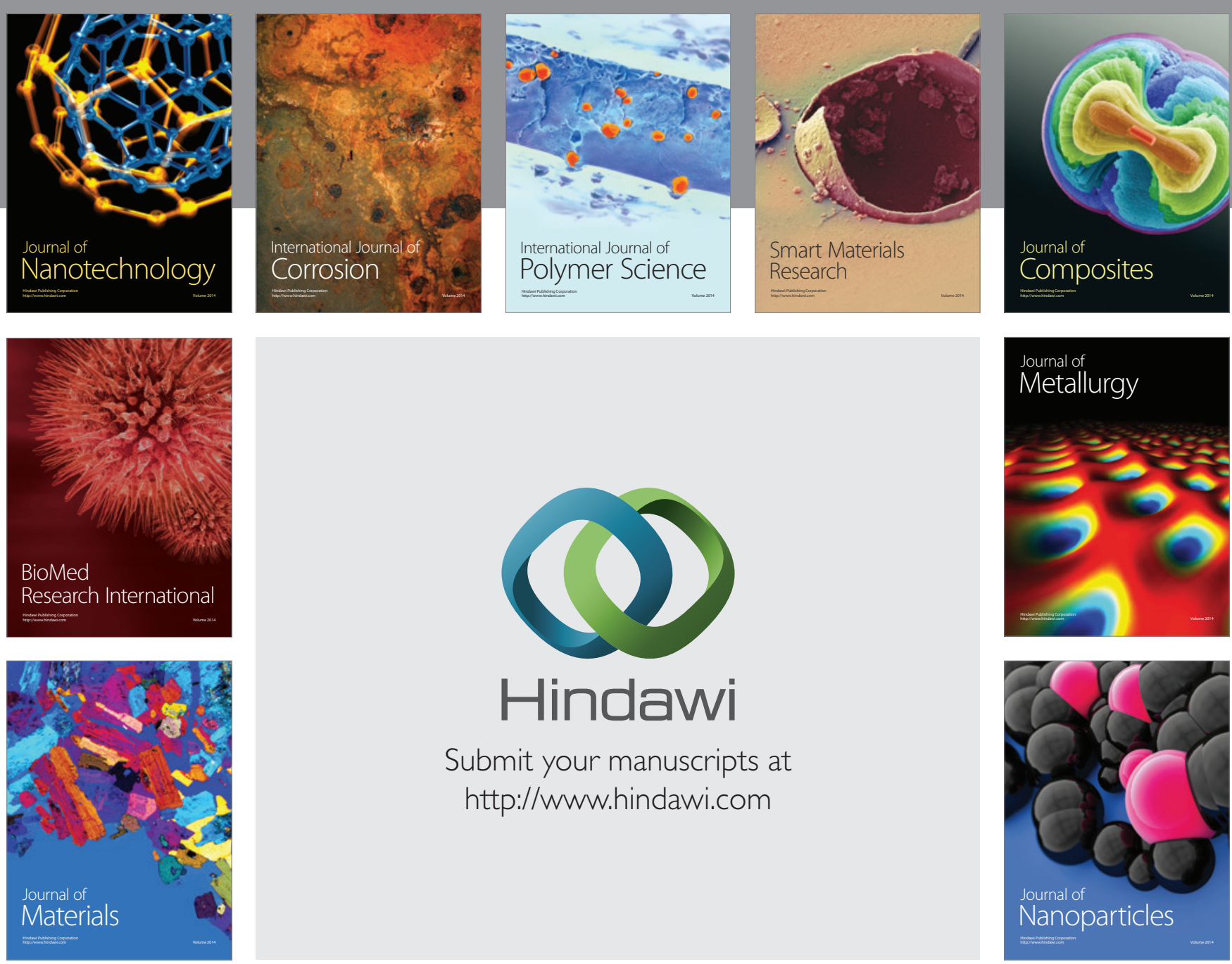

Submit your manuscripts at http://www.hindawi.com
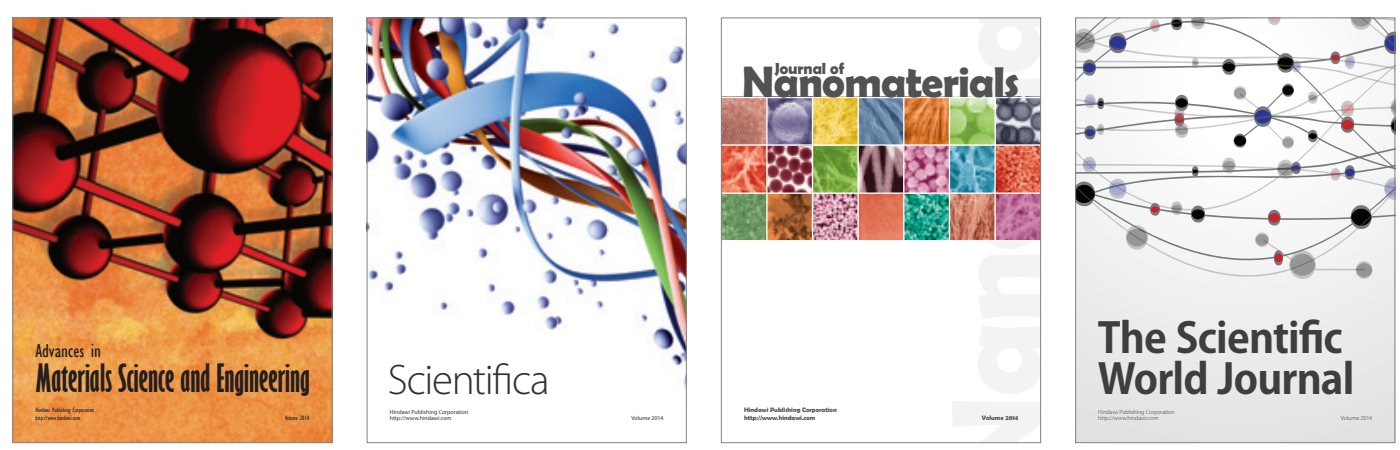

\section{The Scientific World Journal}
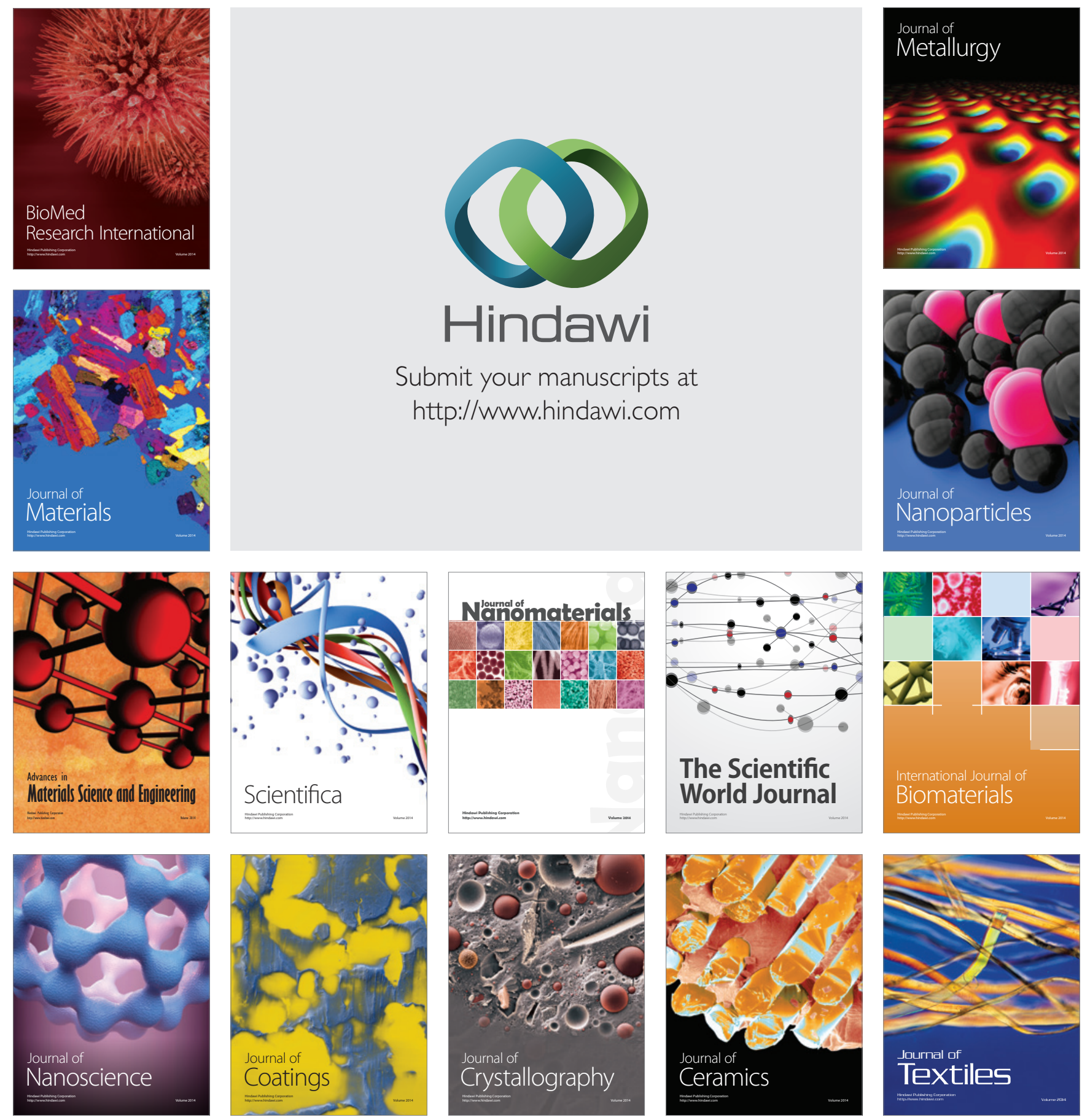